\title{
POTENSI PENGGUNAAN TEMPURUNG KELAPA SEBAGAI ADSORBEN ION LOGAM Fe(III)
}

\author{
NENG MASTIANI $^{1}$, VINA AMALIA ${ }^{1 *}$, TINA DEWI ROSAHDI ${ }^{1}$ \\ ${ }^{1}$ Jurusan Kimia, Fakultas Sains dan Teknologi, UIN Sunan Gunung Djati Bandung, \\ Jl. A.H. Nasution No. 105 Cipadung, Bandung 40614 \\ *alamat email korespondensi: vinaamalia@uinsgd.ac.id
}

\begin{abstract}
Informasi Artikel Abstrak/Abstract
Riwayat Naskah :

Diterima pada 9 Mei

2018

Diterima setelah direvisi pada 8 Juni 2018

Diterbitkan pada 28 Juni 2018

Besi merupakan logam yang paling banyak sekali ditemui dalam kehidupan sehari-hari. Kandungan besi berlebihan di dalam air dapat menyebabkan bekas karat pada pakaian, porselin dan dalam jumlah yang tinggi dapat bersifat sebagai racun bagi tubuh. Pada penelitian ini dipelajari potensi penggunaan tempurung kelapa sebagai adsorben ion logam $\mathrm{Fe}(\mathrm{III})$. Adsorben dari bahan tempurung kelapa disiapkan pada berbagai metode perlakuan awal, yaitu (1) tanpa perlakuan; (2) tanpa lignin (delignisasi); (3) diarangkan; (4) dikalsinasi pada suhu $400^{\circ} \mathrm{C}$; dan (5) dikalsinasi pada suhu $600^{\circ} \mathrm{C}$. Selanjutnya dari masing-masing perlakuan dibagi menjadi dua bagian untuk diaktivasi dan tidak diaktivasi dengan aktivator yang digunakan yaitu $\mathrm{NaOH}$. Konsentrasi ion logam $\mathrm{Fe}(\mathrm{III})$ setelah adsorpsi dianalisis menggunakan AAS. Hasil penelitian menunjukkan perlakuan yang paling efektif dalam menurunkan konsentrasi logam yaitu pada suhu $600^{\circ} \mathrm{C}$, tanpa aktivasi dengan efisiensi $100 \%$

Kata Kunci: adsorpsi; tempurung kelapa; ion logam Fe(III); AAS; FTIR. dan kapasitas adsorpsi sebesar $0,93 \mathrm{mg} / \mathrm{g}$. Berdasarkan hasil penelitian tempurung kelapa efektif digunakan sebagai adsorben untuk penurunan logam besi pada larutan Fe(III) dari konsentrasi awal sebesar 10 ppm menjadi 0 ppm maka ion logam $\mathrm{Fe}$ pada larutan $\mathrm{Fe}$ (III) 10 ppm sudah terserap oleh adsorben tempurung kelapa.
\end{abstract}

Keywords: Adsorption; coconut shell; Fe(III) metal ions; AAS; FTIR
Iron is the metal most often found everyday. Excess iron content in water can cause rust on clothing, porcelain and in high quantities can be as toxic to the body. In this research I will study about the potential use of coconut shell as an adsorbent of Fe (III) metal ions. Adsorbent of coconut shell material is prepared on various initial treatment methods, ie (1) without treatment; (2) without lignin (delignization); (3) nested; (4) calcined temperature $400^{\circ} \mathrm{C}$; And (5) calcined temperature of $600^{\circ} \mathrm{C}$. Furthermore, from each treatment is divided into two parts for activation and not activated, the activator used is $\mathrm{NaOH}$, the concentration of Fe(III) metal ions after adsorption is analyzed using AAS. The results of the study showed that the most effective treatment of the reduction of the metal was at a temperature of $600^{\circ} \mathrm{C}$ with an adsorbent treatment without activation with $100 \%$ efficiency and adsorption capacity of $0,93 \mathrm{mg} / \mathrm{g}$. Based on the results of the research, coconut shell is effectively used as an adsorbent for the decrease of iron metal at Fe(III) solution from the initial concentration of 10 ppm to 0 ppm then the Fe metal at Fe(III) 10 ppm has been absorbed by coconut shell adsorbent.

\section{PENDAHULUAN}

Air merupakan sumber daya alam yang penting bagi semua makhluk hidup. Manusia dalam kehidupan sehari-hari memerlukan air untuk berbagai keperluan mulai dari air minum, mencuci, mandi, dan kegiatan-kegiatan vital lainnya. Oleh karena itu pengolahan air menjadi pertimbangan yang utama untuk menentukan apakah sumber air yang telah diolah menjadi sumber air yang dapat digunakan atau tidak [1].

Pengadaan air bersih untuk kepentingan rumah tangga seperti air minum, air mandi dan sebagainya harus memenuhi persyaratan yang sudah ditentukan peraturan internasional (WHO dan APHA) ataupun peraturan nasional. Dalam hal ini kualitas air minum di Indonesia harus memenuhi persyaratan yang tertuang dalam Peraturan Menteri Kesehatan Nomor 492/MENKES/PER/IV/2010 [2].

Besi adalah salah satu dari unsur penting yang ditemukan dalam air permukaan dan air tanah. Air yang mengandung besi yang terlalu tinggi sangat tidak diinginkan untuk keperluan rumah tangga, karena dapat menyebabkan bekas karat pada pakaian, porselin dan alat-alat lainnya serta menimbulkan rasa yang tidak enak pada konsentrasi diatas $0,3 \mathrm{mg} / \mathrm{L}$ [3].

Pada dasarnya limbah tempurung kelapa sangat melimpah dan dalam pemanfaatannya belum begitu optimal. Biasanya pemanfaatan limbah tempurung kelapa digunakan sebagai bahan bakar sekali pakai. Oleh karena itu limbah tempurung kelapa ini akan dijadikan sesuatu yang 
lebih bermanfaat yaitu sebagai adsorben. Tempurung kelapa sering dianggap sebagai limbah apabila bagian isi kelapa telah dikonsumsi atau hanya digunakan untuk pembakaran, padahal tempurung kelapa memiliki sifat adsorpsi yang baik. Oleh karena itu, dilakukan penelitian mengenai penurunan kadar ion logam $\mathrm{Fe}(\mathrm{III})$ dengan adsorben tempurung kelapa dari berbagai perlakuan awal (tanpa perlakuan; tanpa lignin (delignisasi); diarangkan; dikalsinasi pada suhu $400^{\circ} \mathrm{C}$ dan dikalsinasi pada suhu $600^{\circ} \mathrm{C}$ ).

\section{EKSPERIMEN}

\section{Prosedur}

\section{Preparasi Adsorben}

Tahapan-tahapan dalam penelitian ini meliputi preparasi tempurung kelapa, persiapan bahan untuk adsorben, kemudian dilanjutkan dengan persiapan penurunan ion logam Fe(III) dengan adsorben tempurung kelapa menggunakan instrumen AAS.

\section{Adsorben Tanpa Perlakuan}

Adsorben ini dibuat dari serbuk tempurung kelapa yang telah halus tanpa perlakuan lain. Adsorben dibagi menjadi dua bagian untuk proses aktivasi dan tidak diaktivasi..

\section{Adsorben Tanpa Perlakuan}

Adsorben ini dibuat dari serbuk tempurung kelapa instrumen AAS.

\section{Adsorben Tanpa Lignin}

Serbuk tempurung kelapa sebanyak $5 \mathrm{~g}$ ditambahkan ke dalam $50 \mathrm{~mL}$ larutan $\mathrm{NaOH} 1 \mathrm{M}$ dan didihkan selama 15 menit, selanjutnya ditambahkan $50 \mathrm{~mL}$ larutan $\mathrm{HCl} 1 \mathrm{M}$ untuk menetralkanya. Adsorben kemudian disaring dan dicuci dengan akua DM lalu dikeringkan dalam oven pada $120^{\circ} \mathrm{C}$ selama 3 jam. Adsorben dibagi menjadi dua bagian untuk proses aktivasi dan tidak diaktivasi.

\section{Adsorben Diarangkan}

Tempurung kelapa dibakar sampai menjadi arang, kemudian dibagi menjadi dua bagian untuk proses aktivasi dan tidak diaktivasi.

\section{Adsorben Dikalsinasi Pada Suhu $400^{\circ} \mathrm{C}$}

Serbuk tempurung kelapa $\pm 100 \quad \mathrm{~g}$ dimasukkan ke dalam cawan porselen kemudian dikalsinasi pada suhu $400^{\circ} \mathrm{C}$ selama 6 jam. Adsorben yang sudah dibakar kemudian dibagi menjadi dua bagian, satu bagian dilakukan aktivasi dan tidak diaktivasi.

\section{Adsorben Dikalsinasi Pada Suhu $600^{\circ} \mathrm{C}$}

Serbuk tempurung kelapa $\pm 100 \quad \mathrm{~g}$ dimasukkan ke dalam cawan porselen kemudian dikalsinasi pada suhu $600^{\circ} \mathrm{C}$ selama 6 jam. Adsorben yang sudah dibakar kemudian dibagi menjadi dua bagian yaitu aktivasi dan tidak diaktivasi.

\section{Aktivasi Adsorben}

Serbuk tempurung kelapa dari setiap perlakuan direndam dengan $\mathrm{NaOH} 0,1 \mathrm{M}$ dengan perbandingan (adsorben: $\mathrm{NaOH}$ 2:100 w/v) dan diaduk dengan pengaduk magnetik pada kecepatan $350 \mathrm{rpm}$ selama 30 menit. Adsorben selanjutnya disaring, dikeringkan dalam oven dengan suhu $80^{\circ} \mathrm{C}$ selama 2 jam dan didinginkan dalam desikator, selanjutnya adsorben yang sudah siap digunakan disimpan dalam wadah kedap udara.

\section{Proses Adsorpsi Sampel}

Sebanyak 0,2 $\mathrm{g}$ adsorben untuk masingmasing perlakuan, baik yang diaktivasi maupun tidak diaktivasi dimasukkan ke dalam $20 \mathrm{~mL}$ larutan $\mathrm{Fe}(\mathrm{III})$ dengan konsentrasi $10 \mathrm{ppm}$ kemudian diaduk dengan menggunakan pengaduk magnetik selama 15 menit. Selanjutnya disaring dengan menggunakan kertas saring, lalu dilakukan analisis kadar ion logam $\mathrm{Fe}$ (III) dengan menggunakan AAS pada panjang gelombang $248,3 \mathrm{~nm}$.

\section{Karakterisasi Adsorben dengan menggunakan FTIR}

Serbuk tempurung kelapa dan adsorben yang penyerapannya paling efektif dilakukan karakterisasi dengan menggunakan FTIR.

\section{HASIL DAN PEMBAHASAN}

\section{Preparasi Adsorben}

Pada penelitian ini adsorben yang digunakan yaitu tempurung kelapa. Tempurung kelapa diperoleh dari pasar Gedebage Bandung. Tempurung kelapa dikeringkan di bawah sinar matahari sampai kadar air dalam tempurung kelapa tersebut hilang, setelah kering dan tidak mengandung kadar air 
selanjutnya tempurung kelapa dihaluskan menjadi serbuk. Ukuran partikel sangat berpengaruh terhadap adsorpsi sehingga serbuk tempurung kelapa yang halus lebih efektif untuk dijadikan adsorben karena memiliki luas permukaan yang besar sehingga proses penyerapan ion logam $\mathrm{Fe}(\mathrm{III})$ akan lebih optimal.
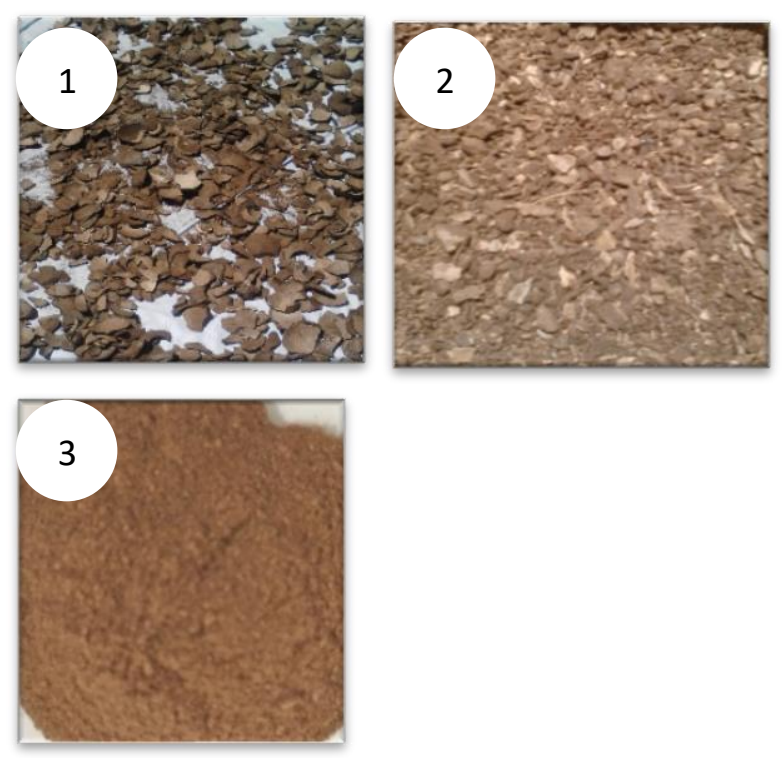

Gambar 1. Tempurung Kelapa: (1) Saat Penghilangan Kadar Air Dengan Dikeringkan Di Bawah Sinar Matahari; (2) Setelah Dibubukkan; (3)Setelah Halus $100 \mu \mathrm{m}$.

Serbuk tempurung kelapa selanjutnya diberi perlakuan aktivasi dan tidak diaktivasi. Tujuan utama dari proses aktivasi adalah menambah atau mengembangkan volume pori dan memperbesar diameter pori yang telah terbentuk pada proses karbonisasi serta untuk membuat beberapa pori baru. Adanya interaksi antara zat pengaktivasi dengan struktur atom-atom karbon hasil karbonisasi adalah mekanisme dari proses aktivasi.

Aktivator yang digunakan dalam penelitian ini adalah aktivator basa yaitu $\mathrm{NaOH} 0,1 \mathrm{M}$. Fungsi aktivasi adalah untuk membuka pori-pori adsorben yang tertutup tar, hidrokarbon, dan zatzat organik lainnya, sehingga memperbesar kapasitas adsorpsi dan melepas matriks yang menyumbat pori-pori adsorben sehingga proses adsorpsi berlangsung lebih optimal. Penggunaan basa ini dimaksudkan untuk mengetahui kemampuan basa dalam memperluas pori dari arang tempurung kelapa yang akan berpengaruh terhadap daya adsorpsi dari arang tersebut, penggunaan aktivator $\mathrm{NaOH}$ dipilih karena bersifat sebagai reduktor (mampu mereduksi bahan lain) dan memiliki keunggunalan diantaranya yaitu bersifat stabil pada temperatur kamar, mudah larut dalam air, tidak terlalu berbahaya dan murah.

Pada penelitian ini dilakukan proses kalsinasi yang bertujuan untuk penghilangan kadar air, karbon dioksida atau gas lain yang mempunyai ikatan kimia dengan materi pada temperatur tinggi di bawah titik leleh dari zat penyusun materi. Panas diperlukan untuk melepas ikatan kimia karena dengan panas maka ikatan kimia akan menjadi renggang dan pada temperatur tertentu atom-atom yang berikatan akan bergerak sangat bebas menyebabkan putusnya ikatan kimia.

Penggunaan variasi suhu $400^{\circ} \mathrm{C}$ dan $600^{\circ} \mathrm{C}$ hal ini bertujuan untuk melihat hasil karbon aktif yang paling baik dari perubahan terhadap faktor suhu, dikarenakan apabila suhu kalsinasi di bawah suhu $400^{\circ} \mathrm{C}$ akan berpengaruh terhadap penghilangan kandungan senyawa organik yang terdapat pada tempurung kelapa. Senyawa organik akan lebih sedikit hilang jika dilakukan kalsinasi di bawah $400^{\circ} \mathrm{C}$ dan jika penggunaan suhu kalsinasi di atas $600^{\circ} \mathrm{C}$ senyawa organik akan hilang karena suhu tinggi dan senyawa yang tersisa adalah karbon.

\section{Adsorpsi Ion Logam Fe(III)}

Berdasarkan hasil analisis menggunakan AAS dengan berbagai perlakuan menunjukan nilai yang bervariasi. Ini dikarenakan setiap adsorben memiliki karakteristik yang berbeda dalam proses adsorpsi, sehingga kondisi yang dibutuhkan juga berbeda. Hal ini dapat dilihat pada Gambar 2 di bawah ini.

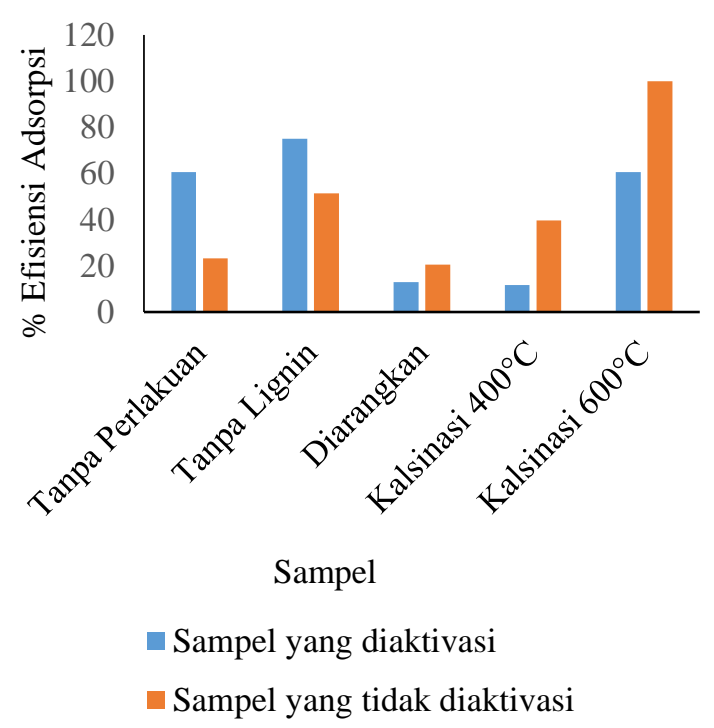

Gambar 2. Kurva Efisiensi Adsorpsi Tidak Diaktivasi dan Diaktivasi 
Berdasarkan hasil penelitian dapat dilihat pada Gambar 2. di atas menunjukkan bahwa penyerapan yang paling baik pada adsorpsi tidak diaktivasi terjadi pada suhu $600^{\circ} \mathrm{C}$ dengan efisiensi adsorben yaitu $100 \%$. Berdasarkan hasil perlakuan efektif pada suhu $600^{\circ} \mathrm{C}$ tanpa aktivasi, hal ini dikarenakan semakin tinggi suhu semakin banyak karbon yang hilang dan menyebabkan berkurangnya pengotor sehingga baik digunakan untuk adsorben.

Pada suhu $600^{\circ} \mathrm{C}$ arang tempurung kelapa mengalami proses karbonisasi sempurna sehingga hampir seluruh senyawa organik kompleks diubah menjadi karbon sederhana dan suhu berpengaruh terhadap proses reduksi ketika dilewati gas hidrogen, semakin tinggi suhu maka akan berpengaruh pada ikatan oksigen dan karbon yang terkandung pada serbuk tempurung kelapa, sehingga terjadi kenaikan kadar karbon pada serbuk arang. Kalsinasi pada suhu $600^{\circ} \mathrm{C}$ juga terlihat bahwa dapat menurunkan logam Fe dalam air dari $9,305 \mathrm{mg} / \mathrm{L}$ menjadi $0 \mathrm{mg} / \mathrm{L}$ sesuai dengan ambang batas maksimum berdasarkan Perarturan Menteri Kesehatan NOMOR 492/MENKES/PER/IV/2010 yaitu 0,3 $\mathrm{mg} / \mathrm{L}$ tentang persyaratan kualitas air minum.

Sedangkan proses aktivasi efektif pada perlakuan tanpa pengarangan yaitu adsorben tidak diarangkan dan dihilangkan ligninnya. Efisiensi adsoben sebesar 75,05\% dengan konsentrasi akhir yaitu $2,101 \mathrm{mg} / \mathrm{L}$. Berdasarkan dari hasil analisis, maka kapasitas adsoprsi dapat dilihat pada Gambar 3.

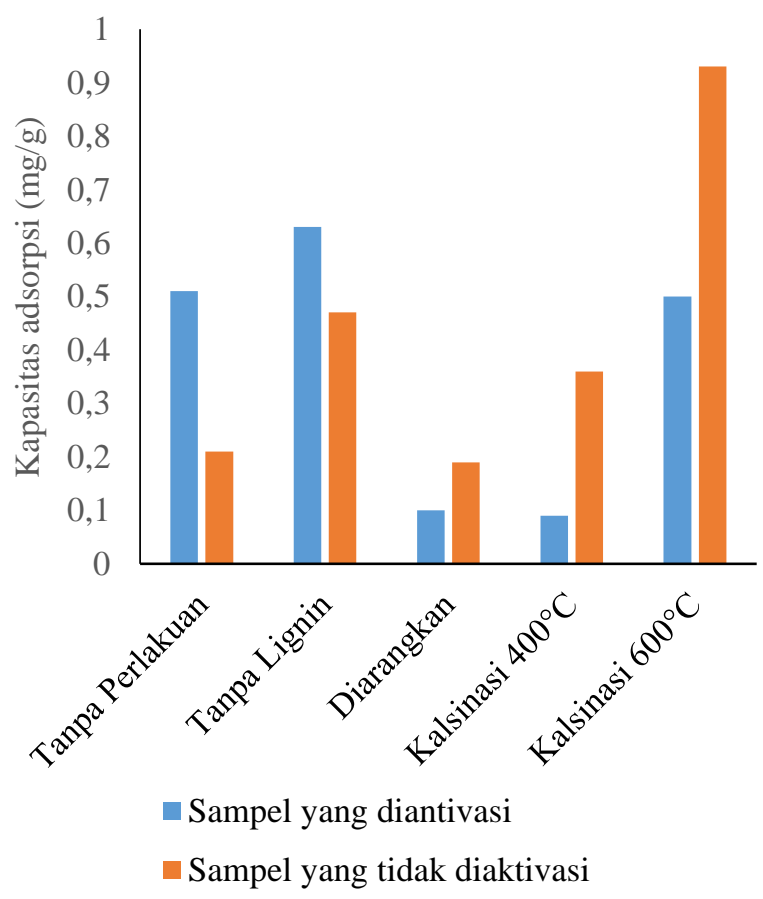

Gambar 3. Kurva Kapasitas Adsorpsi Aktivasi dan Tidak Diaktivasi
Seperti yang dapat kita lihat pada Gambar 3 bahwa adsorben dengan kondisi yang mempunyai kapasitas adsorpsi sebesar $0,93 \mathrm{mg} / \mathrm{g}$ dan efisiensi adsorben sebesar $100 \%$ berada pada perlakuan kalsinasi $600^{\circ} \mathrm{C}$ tanpa aktivasi. Kapasitas semakin besar seiring dengan bertambahnya suhu. Hal ini berkaitan dengan semakin aktifnya gerakan ionion dari cairan ke permukaan adsorben semakin mudah.

Berdasarkan data yang diperoleh efisiensi adsorpsi tanpa aktivasi pada proses tempurung kelapa tanpa perlakuan yaitu $23,20 \%$ dan yang diaktivasi yaitu $60,65 \%$, kemudian untuk kapasitas adsorpsi tanpa aktivasi yaitu $0,21 \mathrm{mg} / \mathrm{g}$ dan kapasitas adsorpsi aktivasi yaitu $0,51 \mathrm{mg} / \mathrm{g}$. Berdasarkan data tersebut dapat dikatakan bahwa efisiensi dan kapasitas adsorpsi mengalami kenaikan setelah aktivasi.

Pada perlakuan penghilangan lignin diperoleh efisiensi adsorpsi tanpa aktivasi yaitu $51,39 \%$ dan yang diaktivasi yaitu $75,05 \%$. Kapasitas adsorpsi tanpa aktivasi yaitu $0,47 \mathrm{mg} / \mathrm{g}$ dan adsorpsi setelah aktivasi sebesar $0,63 \mathrm{mg} / \mathrm{g}$, dari data tersebut dapat dikatakan bahwa efisiensi dan kapasitas adsorpsi mengalami kenaikan setelah aktivasi.

Pada perlakuan adsorben diarangkan diperoleh hasil efisiensi adsorpsi tanpa aktivasi yaitu $20,61 \%$ dan setelah aktivasi sebesar $12,91 \%$, kemudian untuk kapasitas adsorpsi tanpa aktivasi yaitu $0,19 \mathrm{mg} / \mathrm{g}$ dan setelah aktivasi sebesar 0,10 $\mathrm{mg} / \mathrm{g}$, berdasarkan data tersebut dapat dikatakan bahwa efesiensi dan kapasitas adsorpsi mengalami penurunan setelah diaktivasi, hal tersebut dikarenakan penambahan aktivator $\mathrm{NaOH}$ dapat membentuk endapan hidroksida sehingga proses adsorpsi sulit terjadi, serta masih terdapat karbon dan lignin di dalam sampel sehingga terjadi penurunan absorbansi setelah proses aktivasi.

Perlakuan adsorben pada suhu $400^{\circ} \mathrm{C}$ diperoleh hasil efisiensi adsorpsi tanpa aktivasi yaitu $39,59 \%$ dan yang diaktivasi yaitu $11,72 \%$, kemudian untuk kapasitas adsorpsi tanpa aktivasi yaitu $0,36 \mathrm{mg} / \mathrm{g}$ dan adsorpsi diaktivasi yaitu 0,09 $\mathrm{mg} / \mathrm{g}$.

Berdasarkan hasil analisis pada perlakuan adsorben kalsinasi suhu $600^{\circ} \mathrm{C}$ diperoleh hasil efisiensi adsorpsi tanpa aktivasi yaitu $100 \%$ dan yang diaktivasi yaitu $60,51 \%$, kemudian untuk kapasitas adsorpsi tanpa aktivasi yaitu $0,93 \mathrm{mg} / \mathrm{g}$ dan adsorpsi diaktivasi yaitu $0,50 \mathrm{mg} / \mathrm{g}$.

Hal ini dapat dilihat pada hasil penyerapan ion logam $\mathrm{Fe}(\mathrm{III})$ efektif pada perlakuan tanpa aktivasi kalsinasi suhu $600^{\circ} \mathrm{C}$ dengan efisiensi adsorpsi sebesar $100 \%$. Sedangkan setelah perlakuan aktivasi efektif pada perlakuan 
penghilangan lignin dengan efisiensi adsorpsi sebesar $73,76 \%$.

Sama halnya dengan penyerapan ion logam $\mathrm{Fe}(\mathrm{III})$ penurunan efisiensi adsorpsi pada adsorpsi kimia yang telah dilakukan penambahan dengan $\mathrm{NaOH}$ menurun dan sebaliknya pada adsorpsi fisik terjadi kenaikan efisiensi adsorpsi.

Sedangkan pada proses aktivasi efektif pada perlakuan tidak diarangkan dihilangkan ligninnya, ini menunjukkan bahwa untuk penyerapan logam tidak hanya harus melalui tahap pengarangan, tetapi tanpa melalui tahap pengaranganpun tempurung kelapa efektif dijadikan sebagai adsorben [4].

Berdasarkan penelitian yang telah dilakukan dari berbagai perlakuan, hasil aktivasi dan tidak diaktivasi memiliki efisiensi adsorpsi yang berbeda. Seperti yang telah dijelaskan sebelumnya, penyerapan yang paling efektif setelah diaktivasi berada pada perlakuan tanpa pengarangan yaitu tidak diarangkan dihilangkan ligninnya. Sedangkan pada perlakuan tanpa aktivasi penyerapan yang paling efektif berada pada suhu $600^{\circ} \mathrm{C}$. Keduanya efektif dijadikan sebagai adsorben, tetapi perlakuan tanpa aktivasi pada suhu $600^{\circ} \mathrm{C}$ lebih efektif dijadikan sebagai adsorben dengan efisiensi sebesar 100\% dibandingkan dengan setelah aktivasi yaitu tidak diarangkan dihilangkan ligninnya hanya memperoleh efisiensi adsorpsi sebesar 73,76\%. Maka dengan ini penyerapan ion logam $\mathrm{Fe}(\mathrm{III})$ dengan karbon lebih efektif penyerapannya dibandingkan dengan selulosa atau lignin.

\section{Karakterisasi Adsorben dengan FTIR}

Karakterisasi dengan menggunakan FTIR bertujuan untuk menentukan gugus fungsi yang ada pada adsorben tempurung kelapa. Sampel yang dianalisis FTIR adalah serbuk tempurung kelapa dengan berbagai perlakuan setelah diaktivasi dan perlakuan yang paling efektif pada proses tanpa aktivasi [5].

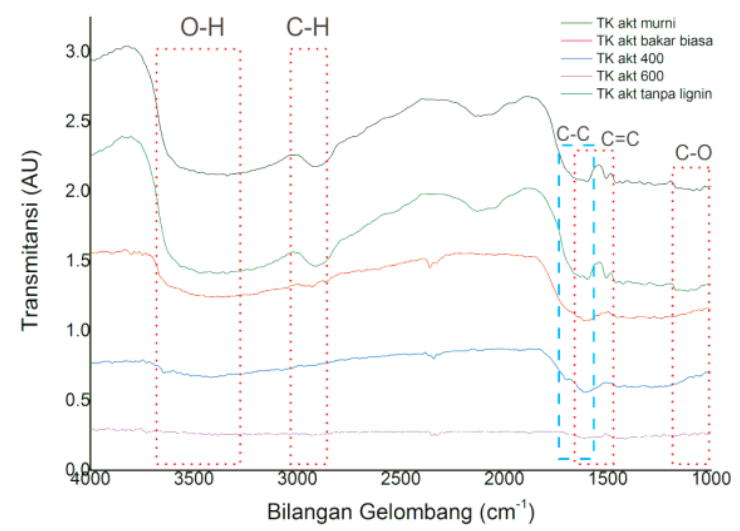

Gambar 4. Spektrum Hasil FTIR Setelah Diaktivasi
Pada penelitian ini adsorben yang diaktivasi dan yang paling efektif pada proses tanpa aktivasi dikarakterisasi dengan menggunakan FTIR. Kemampuan dalam suatu proses adsorpsi dipengaruhi oleh adanya gugus aktif dari adsorben. Oleh karena itu, karakterisasi ini bertujuan untuk mengidentifikasi gugus fungsi senyawa yang ada di dalam adsorben tempurung kelapa setelah diaktivasi. Spektra hasil identifikasi untuk adsorben tempurung kelapa setelah diaktivasi dapat dilihat pada Gambar 4 di bawah ini.

Berdasarkan hasil analisis menggunakan FTIR tempurung pada perlakuan tanpa proses pemanasan, baik tempurung kelapa aktivasi murni atau tempurung kelapa aktivasi tanpa lignin memiliki spektrum pita serapan yang hampir sama. Keduanya memiliki serapan pada bilangan gelombang sekitar $3400 \mathrm{~cm}^{-1}$ yang menunjukkan adanya gugus $\mathrm{O}-\mathrm{H}$ ulur, berasal dari selulosa tempurung kelapa dan serapan $\mathrm{O}-\mathrm{H}$ dari $\mathrm{NaOH}$ yang bertindak sebagai aktivator, mengindikasikan adanya kandungan air dalam sampel. Kemudian hasil spektra FTIR serapan bilangan gelombang sekitar $2900 \mathrm{~cm}^{-1}$ yang menunjukkan adanya ikatan $\mathrm{C}-\mathrm{H}$ yang mengindikasikan adanya senyawa hidrokarbon pada sampel. Pita serapan pada bilangan gelombang sekitar $1600 \mathrm{~cm}^{-1}$ menunjukkan adanya ikatan $\mathrm{C}=\mathrm{C}$ dan serapan pada bilangan gelombang sekitar $1500 \mathrm{~cm}^{-1}$ menunjukkan adanya ikatan C-C dan C-H. Ikatan pada bilangan gelombang sekitar $1300 \mathrm{~cm}^{-1}$ menunjukkan adanya $\mathrm{O}-\mathrm{H}$ tekuk, dan pita serapan $1010 \mathrm{~cm}^{-1}$ yang menunjukkan adanya ikatan C-O.

Hasil analisis FTIR untuk tempurung kelapa dengan perlakuan pengarangan menunjukkan beberapa perbedaan pita serapan. Tempurung aktivasi bakar biasa dan $400^{\circ} \mathrm{C}$, memiliki serapan pada bilangan gelombang sekitar $3400 \mathrm{~cm}^{-1}$ yang menunjukkan adanya $\mathrm{O}-\mathrm{H}$ berasal dari selulosa dan $\mathrm{NaOH}$ tetapi pita serapan pada perlakuan aktivasi $400^{\circ} \mathrm{C}$ memiliki pita serapan yang lemah dibandingkan dengan aktivasi bakar biasa yang memiliki pita serapan lebih kuat. Keduanya memiliki pita serapan pada bilangan gelombang sekitar $2900 \mathrm{~cm}^{-1}$ yang menunjukkan masih adanya ikatan $\mathrm{C}-\mathrm{H}$ walaupun dengan serapan yang lemah. Kedua ikatan tersebut memiliki pita serapan pada bilangan gelombang $1600 \mathrm{~cm}^{-1}$ yang menunjukkan adanya ikatan $\mathrm{C}=\mathrm{C}$, bilangan gelombang sekitar $1500 \mathrm{~cm}^{-1}$ menunjukkan ikatan C-C, kemudian bilangan gelombang sekitar 1050 $\mathrm{cm}^{-1}$ yang menunjukkan adanya ikatan C-O. Sedangkan untuk tempurung kelapa kalsinasi $600^{\circ} \mathrm{C}$ hanya memiliki pita serapan pada bilangan gelombang $1600 \mathrm{~cm}^{-1}$ menunjukkan adanya ikatan 
$\mathrm{C}=\mathrm{C}$, dan pita serapan pada bilangan gelombang $1500 \mathrm{~cm}^{-1}$ menunjukkan adanya ikatan C-C.

Pita serapan yang sangat lemah juga masih terdapat pada bilangan gelombang $3400 \mathrm{~cm}^{-1}$, dan $2900 \mathrm{~cm}^{-1}$, menunjukkan masih adanya sedikit ikatan $\mathrm{O}-\mathrm{H}$, dan ikatan $\mathrm{C}-\mathrm{H}$. Hal ini terjadi karena pada proses kalsinasi dengan suhu $600^{\circ} \mathrm{C}$ tempurung kelapa mengalami proses karbonisasi sempurna, sehingga hampir seluruh senyawa organik kompleks berubah menjadi karbon sederhana. Pada proses karbonisasi terjadi penguraian bahan-bahan organik yang terkandung di dalam tempurung kelapa. Pada perlakuan bakar biasa terjadi penguapan air, pada suhu kalsinasi $400^{\circ} \mathrm{C}$ terjadi penguraian lignin dihasilkan lebih banyak ter sedangkan larutan piroglinat dan gas $\mathrm{CO}_{2}$ menurun tetapi gas $\mathrm{CH}_{4}, \mathrm{CO}$ dan $\mathrm{H}_{2}$ meningkat pada suhu $600^{\circ} \mathrm{C}$ merupakan tahap pemurnian atau peningkatan kadar karbon.

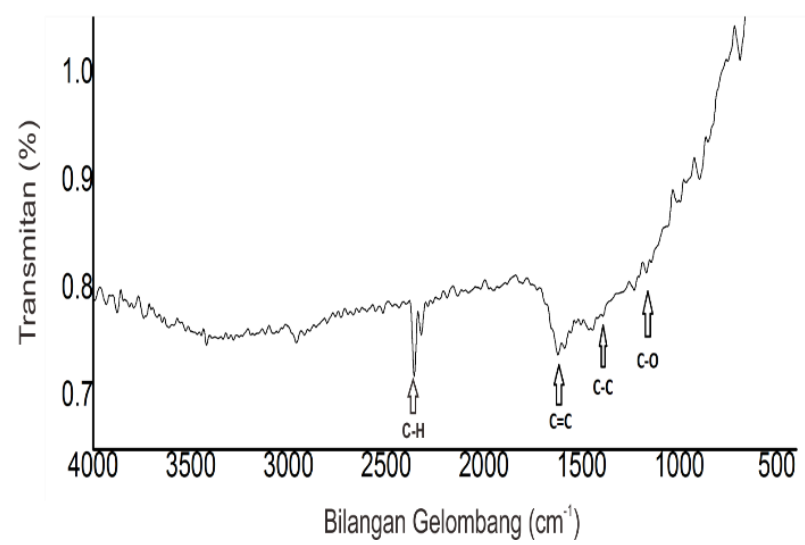

Gambar 5. Spektrum Hasil FTIR Kalsinasi $600{ }^{\circ} \mathrm{C}$ Tanpa Aktivasi

Berdasarkan penelitian yang telah dilakukan dapat dilihat pada Gambar 5 menunjukkan bahwa perlakuan tanpa aktivasi optimum pada kalsinasi suhu $600^{\circ} \mathrm{C}$ dan memiliki pita serapan yang lemah pada bilangan gelombang sekitar $3112 \mathrm{~cm}^{-1}$ menunjukkan adanya ikatan $\mathrm{C}-\mathrm{H}$, pita serapan pada bilangan gelombang sekitar $1612 \mathrm{~cm}^{-1}$ menunjukkan adanya ikatan $\mathrm{C}=\mathrm{C}$, dan pita serapan pada bilangan gelombang sekitar 1445 $\mathrm{cm}^{-1}$ menunjukkan adanya ikatan C-C.

\section{SIMPULAN}

Dari hasil penelitian ini dapat diambil kesimpulan bahwa tempurung kelapa efektif dijadikan sebagai adsorben ion logam $\mathrm{Fe}(\mathrm{III})$. Perlakuan yang paling efektif dijadikan sebagai adsorben ion logam $\mathrm{Fe}$ (III) berada pada perlakuan tanpa aktivasi yaitu proses kalsinasi suhu $600^{\circ} \mathrm{C}$ sebesar $0 \mathrm{mg} / \mathrm{L}$ dengan efisiensi adsorpsi sebesar $100 \%$ dan kapasitas adsorpsi sebesar $0,93 \mathrm{mg} / \mathrm{g}$. Hasil analisis dari setiap perlakuan dikarakterisasi dengan FTIR menunjukkan adanya gugus $\mathrm{O}-\mathrm{H}$ ulur, ikatan $\mathrm{O}-\mathrm{H}$ tekuk, ikatan $\mathrm{C}-\mathrm{H}$, ikatan $\mathrm{C}=\mathrm{C}$, ikatan C-O dan ikatan C-C.

\section{REFERENSI}

[1] Kusnaedi,. Jakarta: Penebar Swadaya, 2002.

[2] Permenkes, "Persyaratan Kualitas Air minum," vol. 492, 19 April 2010.

[3] Sya'ban, Penyerapan Ion Alumunium dan Besi dalam Larutan Sodium Silikat menggunakan Karbon Akti. Jakarta: Fakultas Sains dan Teknologi. UIN Syarif Hidayatullah, 2010.

[4] Marwati and Siti , Teknik Analisis dengan Atomic Absorption Spectrophotometry. Yogyakarta: FMIPA Universitas Negeri Yogyakarta, 2015.

[5] Unang Supratman, Elusidasi Struktur Senyawa Organik. Bandung, 2010. 